\title{
DE NEGERPREDIKANT JACOBUS ELISA JOANNES CAPITEIN,
}

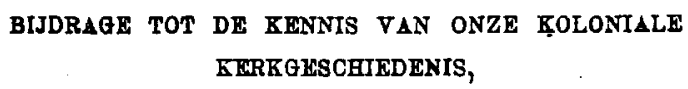

Dr. A. FEKHOF.

II.

\section{$\S 3$.}

Capitein's werkzaamhid te St. Grorge D'Elmina.

BLoeitidd.

St. George D'Elmina was het schoonste en sterkste fort op de Goudkust van Afrika. Reeds in 1481 waren de Portugeezen met den bouw van het Hoofdkasteel begonnen, en tachtig jaar daarna was het roltooid. Graaf Maurits van Nassau, gouverneur van Brazilië, vermeesterde het in 1637 voor de Nederlanders, in wier bezit het bleef tot April 1872, toen het aan de Engelsche regeering werd afgestaan, in wier handen de Goudkust is gebleven tot op dezen dag 1). Voor de West-Indische Compagnie

1) Zie: C. A. Jeekel, Onze bezittingen op de kust van Guinea:, Amst. 1869, blz. 24-30; The Encyclopaedia Britannica, Cambridge 1910, Vol. IX, p. 297. Een vitvoerige literatuur-opgave kan men vinden in: Catalogus der Koloniale Bibliotheek, door G. P. Rouffaer en W. C. Muller, 's-Grav. 1908, zie : het Rèegister s.v. Guinee (Kust van); ook: Eerste Supplement, 's-Grav. 1915, in 't Register, onder hetzelfde woord. XIII. 
was het de stapelplaats van goud, elpenbeen en slaven, een van de belangrijkste der vijftien handelsplaatsen, welke zij op de Goudkust, in het midden der 18de eeuw bezat.

Naar deze plaats nu, vanwaar de neger Jacobus Elisa Joannes Capitein in het jaar 1728 naar Nederland was weggevoerd, keerde hij als geordend predikant in 1742 terug, om den kolonisten en zijnen landslieden het Evangelie te brengen. Hij was de oprolger van ds. Isaacus Ketelanus, die 29 October 1734, om zün kwaad gedrag en ergerljkk leven door de Bewindhebberen van de WestIndische Compagnie was ontslagen 1 ).

Orer deze kust, waar in dit jaar een getal van 241 personen in dienst van de Compagnie stond, onder welke 107 te St. George D'Elmina, voerde de directeurgeneraal Jacob de Petersen het bewind ${ }^{2}$ ), toen Capitein

1) Resolutien van de Vergadering der Thienen - W.I.C., No. 9, fol. 93. (29 Oct. 1734). Deze handschriften bevinden zich in het Rijksarchief te 's-Gravenhage.

2) Volgens de "Generale Monsterrolle", ultimo December 1742 opgemaakt, waren er te D'Elmina 107 -personen, onder wie 13 bestuurders, verder 3 op 't Comptoir Generaal; 7 op 't Comptoir der Secretarie ; 2 op 't Comptoir ter Soldie; 3 op 't huys ter Negotie ; 2 in het Magasijn; 3 in de Chirurgijnswinkel; 1 in het Hospitaal, dan 12 trainspersonen en de rest militairen. In het geheel waren er in dit jaar op de Slavenkust 241 personen, te weten: 107 aan D'Elmina; 12 aan St. Jago; 14 an Axim; 4 aan Hollandia; 4 aan Accoda; 6 an Coutry; 4 aan Taccorary ; 9 aan Saccondé; 6 aan Chama ; 7 aan Commany ; 9 aan Mourée; 13 aan Cormantin; 6 aan Apam; 7 aan Bercoe; 21 aan Accra; 1 aan aan de loge Pattakkery; 2 aan de loge Eepée; 2 op de boot de Goede Faam'; 3 op de boot ,'t Goed Succes'; 4 op de boot ,'t Goed Fortuyn'. Brieven en Papieren van Guinea aan de Vergadering der Thienen W. I. C., No. 113, fol. 146r-154'. (Rijks-archief te 's-Gravenhage).

Het is nog altijd een niet opgeloste zaak - en het zou de moeite van een nauwgezet onderzoek loonen - hoe het is gekomen, dat vele van de "bediendens" der Compagnie over het algemeen in onze koloniên buitenlanders waren. Van de personen op de monsterrol van dit jaar te D'Elmina komen er o. a. uit Hessen, Danzig, Hannover, Oldenburgh, Leipzig, Gent, Meklenburg, Brussel. Keulen en elders. Ten opzichte van Noord-Amerika geldt een zelfde verschijnsel, waarop A. J. F. van Laer, Early Records of the City and County of Albany and Colony of Rensselaerswyck, Albany 1916, Volume 2, p. 11 de aandacht vestigt. Daar komen ze hoofdzakelijk uit Oost-Friesland, Oldenburg en Sleeswijk. Holstein. Van Laer zegt: "Just what the cause of emigration from 
er den 8sten October 1742 op het slavenschip "De Catharina Galey", waarvan Andries Graan de gezagvoerder was, arriveerde. De Petersen ontving den nieuwen predikant hartelijk, en schreef 22 October 1742 aan de $\mathrm{Be}$ windhebberen van de West-Indische Compagnie, dat Capitein „aanbelangende sijn carracter en predikingh". zeer wel voldeed, en dat, als de predikant op deze wïze bleef voortgaan, zijn onderwijs ${ }_{n}$ van veel heylsaamer uytwerkinge soude kunnen weesen, als sommige sig voor desselfs komste, verbeeld (hadden)". De directeur.generaal beloofde "de noodige diligentie" to zullen aanwenden, om den predikant hierin behulpzaam te zijn 1).

Ook Capitein was over de ontrangst anvankelijk best te spreken. Hij berichtte 21 October 1742 aan de Bewindhebberen, dat de directeur-generaal hem "in alle vrundelijkheyd en toegenegenheyd" had ontrangen, en hem beloofd had in alles de behulpzame hand te zullen bieden, om onder des Heeren medewerkende genade, het heilzaam oogmerk, waartoe de Bewindhebberen hem uitgezonden hadden, in reiligheid te bereiken 2). Op den 21sten October 1742 hield Capitein zijne intree-predikatie, welke hij met den huiswaarts keerenden Andries Graan had willen medegeren, om haar in Nederland, met goedvinden der Bewindhebberen, te laten drukken. Echter niet in dit jaar, doch eerst in het rolgende, zond hij ze naar het raderland 3), waar zij inderdaad gedrukt is, blijkens een exemplaar er van, dat thans voor mij ligt.

Deze predikatie voert den volgenden titel: ${ }_{n}$ Het groote genadeligt Gods in zyne dienaaren onder de bediening

these regions was, is an interesting question to which as yet no definite answer can be given". Dat de bewoners van armelijke streken zich ook op onze vloot lieten aanmonsteren, orn hun lot te verbeteren, vindt zijn bevestíging bij Johan E. Elias, Schetsen uit de geschiedenis van ons Zeewezen (1568-1652), 's-Grav. 1916, blz. 58.

1) Brieven en Papieren van Quinea aan de Kamer van Amsterdam - W.I.C., N'. 488, fol. 710r-711'. (Rïks-archief te's-Gravenhage).

2) Bijlage I (21 Oct. 1742), blz. 244.

3) Bijlage II (15 Februari 1743), blz. 247. 
der genade, ontdekt in eene intree-predicatie over 2 Corinthen IV:6, door Jacobus Elisa Joannes Capitein, Africaanschen Moor, Predicant op St. George d'Elmina, En op zyn Eerw. verzoek uitgegeven door Hieronymus de Wilhem. Te Leiden by Jacobus de Beunje, en t' Amsterdam by $\mathrm{De}$. Janssoons van Waasberge, Boekverkopers, 1744" 1).

Aan de eigenlïke predikatie doet Capitein eene $n$ opdragt" aan de Bewindbebberen, als blijk zijner gehoorzaamheid en uiting zijner dankbaarheid, voorafgaan. Hij zegt naar St. George D'Elmina gekomen te zijn „om, eensdeels, de Christenen te dezer plaatse te versterken in de eens aangenoomene leer, die naar de godzaligheid is, in de hoope des eeuwigen leevens, en anderdeels, om (s)yne maagschappy naar den vleesche, de Moorsche heidenen, de verborgenheid des Evangeliums, welke in andere eeuwen hun niet is bekent gemaakt, naar de voorligting der eeuwige roorzeggingen, op het voetspoor der heilige Evangelisten en Apostelen, te openbaaren". Aan het slot van de opdracht wenscht hij den Patronen toe, dat het .den Koning der Eeuwen behagen moge, hun leven tot "nut van land en kerk uit te strekken tot eenen gezeegenden ouderdom en gekroonde gryzigheid", en voegt er dan bij: „Hy vervulle $\mathrm{O}$ Wel-Ed. Groot-Agtbare huizen en geagte personen met de zeegeningen des bemels van boven, met de zeegeningen des afgronds, die daar onder ligt, wet zeegeningen der borsten ende der baarmoeder, met de inkomsten van het Oosten, ende van het Westen, van het Zuiden, ende van het Noorden! hy doe U Wel-Ed. Groot-Agtbare dus overvloeyen van inkomsten, tot het zilver $\mathrm{zy}$, gelyk steenen, ende de cederen, als wilde vygeboomen, die in de laagte zyn!"

Bij de rerklaring van zijn tekst: „Want God, die gezegd heeft, dat het ligt uit de duisternisse zoude schïnen, is degeene, die in onze herten gescheenen heeft, om te

1) Een exemplaar van dit boekje, quarto-formaat, is in de Koninklijke Bibliotheek te 's-Gravenhage. 
geeven rerligting der kennisse der heerlijkheid Gods in het aangezigt van Jesus Christus", laat hij de verbondsleer van Coccejus duidelïk uitkomen, en houdt zich overigens, evenals in zijne vorige preeken ${ }^{1}$ ), aan het voorschrift dier dagen. Of zijne hoorders - eene vergadering van meerendeels onontwikkelde kolonisten - er met genoegen naar geluisterd zullen hebben, en of zijne zwarte landslieden iets van deze scholastisch-dogmatische uiteenzettingen begrepen zullen hebben, kan met reden worden betwijfeld.

De methode wijkt zeker ver af van de opvattingen onzer dagen betreffende de heiden-prediking ${ }^{2}$ ). De "Toepassing" is echter veel belangwekkender; daarin overziet hij zijn leven en spreekt hï enkele personen en college's toe. Wï achten het niet ongeschikt een enkele bladzijde af te drukken, die dienen kan als proeve van Capitein's prediking:

„Ziet daar, myne Toehoorders! dus hebben wy beschout, hoe de algenoegsaame God, onder de luisterryker bedeeling des Nieuwen Verbonds, alles werkstellig maake om Zondaaren te behouden, en alles naakt ontdekke, in het Erangelium, en openbaare, door zyne Heilgezanten, opdat de geene, die onder dit ons Evangelium rerlooren gaan, niet te rerontschuldigen zouden zijn.... Want op deezen huidigen dag maake ik een begin van mynen dienst in dit gedeelte van des Heeren Oogst. Immers! nadat de God der veelvuldige genade my, over veertien jaaren, uit ditzelve land, uit deeze zelve plaatse, hadde geleid naar het gezeegend Holland, gelyk als een Arend over zyne jongen zweert, zyne vleugelen uitbreid, die opneemt, ende draagt op zyne vlerken, ben ik nu, in vreede, in ditzelve land, in dẹeze zelve plaatse, wedergekeert. Myne ziel word aengedaan over de wegen, die God, tot hiertoe, met my gehouden heeft, want daar ik eertyds in lichaamelyke slaverny, ja! in

1) Zie hiervóór, Deel XIII (1916), blz. 165-167.

2) De zending is in deze tijden zuiver kerkelijk, trad echter niet opvoedkundig op, en liet het zieleleven niet tot zijn recht komen. Men wilde van de kerk buitenslands een kopie maken van de kerk in het vaderland. Zie hierover de belangrijke artikelen van: A. M. Brouwer, Boe te prediken voor Heiden en Mohammedaan? in : Mededeelingen van wege het Nederlandsch Zendelinggenootschap, Deel 60 (1916) en daarin vooral zijn karakteristiek van de Oud-Hollandsche zending, blz. 2:40-24:3. 
de hart- ei zinnen-verduisterende magt des Duivels myne teedere jaaren en ouderdom zoude doorgebragt hebben in dit land, gelyk myne Landsgenooten, tot op deezen huidigen dag, ondervinden moeten, bragt hy my over in het gezeegend Holland, alwaar Hy my, niet alleen gav, brood om te eeten ende kleederen om aan te trekken, maar ook my, onder het getal der Godgewyde leereade Jeugd, op 's Lands .Hooge School, langs zielen-ontroerende wegen, ten zynen dienste, deed uitrusten, zoodat my ook nu een lot gegeeven zy onder de voortreffelyke Dienaars en uitdeelers der ziel-zaligende verborgenheeden Gods. Myne ziele gaat uit wegens verwondering over allen yver en naarstigheid, met welke my de Leer der twee Verbonden, $\operatorname{van}$ geene de minste onder des Heeren Dienaaren, met sterke roepingen, in den gebede en traanen, overgeleevert $\mathrm{zy}$, als een dierbaar pand, tot behoudenisse ran myne eigene ziele, en tot inwinning van veele zielen, tot het Koninkryk van Koning Jesus. Myne ziele gedenkt ook nog aan de belofte, die ik den Heere gedaan hebbe, en die ik, tot blydschap van het geslagte der kinderen Gods, vrymoedig meenigmaalen hebbe vermeld, dat, wanneer God met my zoude geweest zyn, en my zoude gegeeven hebben brood om te eeten ende kleederen om aan te trecken, ende ik ten huise myns Vaders in vreede zal weedergekeert zijn, zoo zal de Heere my tot eenen God zijn. En de Heere heeft het ook gedaan, zoodat wy nu voor U lieder aangezigte staan, om wederom het ligt des zaligen Evangeliums, in dit Huis te doen schynen, tot de Heer eene reine spraake wende tot de volkeren. Zoo dan, myne geliefde! zoo ik wensche, myne blydschap, ende kroone tegen den grooten dag! ontfangt my, als uwen wettigen Leeraar, die voor uwe, voor de eeuwigheid geschaapene zielen, waaken zal, als die rekenschap geoven zal; ontfangt my met liefde, om des woords wille, dat my toe-

- betrout is, en toont in allen uwen handel, dat de nagt nu voorbygegaan is, en dat het waaragtig ligt schyne. Laat ons de werken des Duyvels afleggen en verbreeken, on aandoen de waapenen des Ligts" ").

Hierop volgen dan eenige toespraken, tot den directeurgeneraal, de Raden der Afrikaansche kust, en de gemeente.

1) Jacobus Elisa Joannes Capitein, Het groote genadeligt Gods, Leiden \& Amsterdam, 1744, blz. 23-26. 
Capitein was nu predikant te St. George D'Elmina en bekleedde, met een traktement van 100 gld. per maand, den tweeden rang onder de „bediendens" van de Compagnie ${ }^{1}$ ). Als "rantsoen" kreeg bij yoor de helft van de maand Norember 1742: „12 ponden vleesch, 6 ponden speck, $4 \frac{1}{2}$ kannen boonen, $41 / 2$ kannen erwten, $41 / 3$ kannen gordt, $11 / 8$ kannen oly, 3/4 kannen azijn, 135 kantjes" ${ }^{2}$ ).

Het ligt voor de hand, dat Capitein nu weldra begon het kerkelïk leven te St. George D'Elmina in te richten. Hoe hij dit deed heeft hij 15 Februari 1743 uitroerig aan de Bewindhebberen geschreven, welk document hierachter als bïlage $\Pi I I$ is opgenomen. Een kerkje zal er vermoedelijk reeds geweest zijn, als wij mogen aannemen, dat de 18 greenen balken waarom gerraagd wordt, voor reparatie zouden dienen ${ }^{3}$ ). Van eenige poging tot bouw van een kerk hooren wij tenminste tijdens Capitein's verbläf niets. Iederen Zondag verklaarde hij een vrijen tekst, en des Donderdag's predikte hij over den Heidelbergschen Catechismus. Capitein deelt zelf over zïne wijze van prediken mede: ${ }_{n}$ Deese leerredenen geschieden niet soo seer wederleggender als wel stellender wyse, tot verbeetering ende tot onderwysing die in de regtraerdigheyd is". Het getal hoorders was niet groot, want de meeste in woners waren Roomsch4),

1) Capitein verdiende na den dir. gen. De Petersen, die 300 gld. traktement per maand genoot, het meest. Het laagste salaris hadden de assistenten, zijnde 16 gld. per maand. Brieven on Papieren van Guinea aan de Vergadering der Thienen - W.I.C., No. 113, blz. 169r.

2) Brieven en Papieren aan de Kamer van Amsterdam - W.I.C., No. 488, fol. 718 r.

3) De greenen balken uit Nederland afkomstig konden veel langer duren dan de inlandsche; dadrbij kwamen dan aankoop en verzending nog niet zoo hoog, als de onkosten van kappen en kano-loonen van Boutry af naar St. George D'Elmina. Brieven en Papieren van Guinea aan de Kamer van Amsterdam - W.I. C., N0. 488, blz. 753z (15 Febr. 1743).

4) De Roomschen mochten hunnen godsdienst niet uitoefenen. De Bewindhebberen schreven 18 April 1743 aan De Petersen, dat hij aan de Brazilianen, die te St. George D'Elmina $\mathrm{k}$ wamen om de tienden te bebetalen, „by oogluykinge" mocht toelaten hunne godsdienstplechtigheden waar te nemen, doch alleen door priesters, die ze zelf op de schepen hadden medegebracht, en dic zij ook weder moesten medenemen. Roomsche geestelijken of missionarissen mochten zich in geen geval in 


\section{6}

of Luthersch '); het aantal lidmaten bedroeg niet meer dan 17. Behalve den dienst op Zondag en Donderdag, hield hij nog elken Maandag "een catechisatie" over „Het kort Uyttreksel van de Leere der Waerheyd", die echter ook weinig werd bezocht, aangezien de menschen bunne dagelïksche bezigheden hadden.

Op den $2^{\text {den }}$ Norember 1742 , dus al spoedig na Capitein's aankomst, werden twee ouderlingen benoemd, met name Antonius van Lokhorst, provisioneel kommies en boekhouder ter soldij, en Jan Romeijn, de vaandrig op D'Elmina, „beide luyden van een onbesproocken leeven en seer ordentelijck gedrag" "). Diakenen werden niet benoemd, om de eenvoudige reden, dat ,hunne ampt hier geene plaets kan hebben", al was Capitein zelf ran gevoelen, dat zij, was het dan niet voor de armen, toch wel voor ziekenhuis of school, konden collecteeren ${ }^{3}$ ).

Van de sacramenten bediende hij 18 November 1742 den H. Doop aan een kind uit Christen-ouders geboren; doch de viering van het $\mathrm{H}$. Arondmaal had roorhands niet plaats, en dat om twee redenen. De eerste was, dat die 17 lidmaten hunne attestatiën niet hadden medegebracht, zeker, omdat zij dachten, dat er te St. George D'Elmina geen kerkelijke gemeente wezen zoude 4 ); eerst moesten deze uit het vaderland overgezonden worden, of moesten zij opnieuw belijdenis des geloofs afleggen alvorens „het

St. George D'Elmina vestigen. Ook keurden de Bewindh. het af, dat de „bediendens" zouden gebruikt worden voor het daar ter plaatse bouwen van een Roomsche kapel voor de Brazilianen, waarvoor, naar men had vernomen, materialen bij de kamer van Zeeland waren aangevraagd. Brieven naar Guinea van do Thienen - W.I.C., No, 57, fol. 59r-" (18 April 1743). (Rijks-archief te 's-Gravenhage).

1) Doordat er zooveel buitenlanders onder het Compagnies-volk was (zie hiervóór, blz. 210), was het getal Lutherschen aanzienlijk.

2) Zie ook: Missive van dir.-gen, De Petersen uan de Bewindh. v. d. W. I. C. in: Brieven on Papierén van Guinea aan de Kamer van Amsterdam - W. I. C., N". 488, lol. 749 r (15 Febr. 1743).

3) Zie ook: Bijlage $X$ (21 Mei 1746), blz. 269.

4) Om deze reden hadden ook de kolonisten in Noord-Amerika hunne attestatiēn viet medegebracht. Zie mijn : De Hervormde Kerk in NoordAmerika, 's-Grav, 1:413, Dl. I, blz. 40, en : Lijlage X (21 Mei 1746), blz. 270. 
bondsegel des Heyligen Arondmael" aan hen kon worden uitgereikt. Een tweede reden, en van ernstiger aard, was eene ingewortelde gewoonte, die de waardige viering van bet sacrament belemmerde. Welke was die gewoonte?

De mannelijire leden der gemeente leefden in een soort huwelijk met de negerinnen of tapoejerinnen - afstammelingen van eenen blanken vader en zwarte moeder hetgeen men in de volkstaal "calacharen" noemde. Deze personen nu vonden geen vrijmoedigheid - en volgens Capitein terecht -, om tot de tafel des Heeren te naderen, daar zij door hun aanzitten het verbond Gods zouden ontheiligen en Gods toorn over de gansche gemeente verwekken. Deze gewoonte was ook vrij algemeen, al maakte de directeur-generaal hierop een loffelijke uitzondering. Wat moest Capitein er aan doen? In zijne instructie ${ }^{1}$ ) stond wel, dat men alle ontuchtig leven met bekwame vermaning en berisping moest bestraffen, doch dit kwaad was zoó ingeworteld, dat het naar Capitein's oordeel alleen door "uytgesogte texten van het Heylig Woord" scheen bedwongen te kunnen worden. Capitein verwachtte hierover nog nadere ordre.

Nog meer dan voor den kerkendienst gevoelde Capitein voor den schooldienst. Reeds in dezelfde maand, warin hij te St. George D'Elmina was aangekomen, richtte hij voor negerkinderen en tapoejers een godsdienst-school op. Hii kreeg daarvoor van den onder-equipagemeester Hendrik Huytingh het grootste en bekwaamste vertrek van het geheele Hoofdkasteel, zijnde behalven de wooninge van den schoolmeester, Hollandse maat lang 42 roet en 7 duym, en breet 14 roet en 4 duym binnen s'werks" 2 ). De eerste beginselen der "letterkonst" werden door den schoolmeester Abraham Suurdeeg onderwezen. Toen deze was overleden 3) volgde een zekere Jan Boying hem op,

1) Deze kennen wij niet.

9) Brieven en Papieren van Guinea aan de Vergadering der. Thienen W.I. C., No. 113, fol. 487 r.

3) Bijlage VIII (29 Oct. 1744), blz. 261. 
die na zijn overlijden op 17 Maart 1744 1), werd vorvangen door Pieter Ernestus Schutsler, die repatriëerde ?), on wiens plaats nu door Adrianus van Waghem werd ingenomen ${ }^{3}$ ). Al deze veranderingen in personeel zullen zeker aan het onderwijs niet bevorderlijk zijn geweest en Capitein grooten last hebben. veroorzaakt.

Het getal kinderen, die dagelijks Capitein's school bezochten, was circa 18 à 20 "s0o zwarten als affzetsels van blancken". Dit was niet veel, en hiervoor waren verschillende redenen. Niet, dat de predikant zijn plicht rerzuimde. Integendeel. De directeur-generaal De Petersen schrijft over bem 15 Februari 1743 , dat hij ,by continuatie heel seer voldoet, en preuvenen geefft, dat hy sijn tijd na behooren besteet beefft, en verders alle vlijt aanwrent, om de kinderen van de Naturellen te doen onderwyzen, en de beginselen der christelyke religie in te boesemen" 4). Doch het lag hoofdzakelijk aan de ouders der kinderen. Capitein zegt zelf in zün verslag, waaraan wij telkens ontleenen (bïlage III), dat deze ouders geen nuttigheid zagen in de letterkonst. Ook De Petersen merkt op, dat de ouders lieten boodschappen, dat hunne kinderen "eerst moesten leeren swemmen on met steenen werpen, on dan zoude school koomen" 4), waarbij nog kwam, dat zwarte kinderen evenmin als blanke gaarne naar school gaan. Voorts waren de scholieren voor het meerendeel jongens, hetgeen uit het volgende verklaard moest worden.

De $z$ warten zonden hunne meisjes niet „nadien sy van gevoelen zijn, dat deese, wanneer sy leesen en schryven

1) Missive van Jacob de Petersen aan de Bewindh. der W.I.C. (1 Mei 1744) in : Brieven on Papieren van Guinea aan de Kamer van Amsterdam - W. I. C., No. 489, fol. 120v.

2) Bijlage XI (13 Mei.1746), blz. 273. Schutsler repatrißerule 1 Juli 1745.

3) Missive van Jacob de Petersen aan de Bewindh. der W.I.C. (1 Juli 1745) in: Brieven en Papieren van Guinea aan de Vergadering der Thienen - W.I.C., No. 113, fol. 321r. Ook: fol. 54ع.

4) Missive van Jacob de Petersen aan de Bewindh. der W.I.C. (15 Febr. 1743) in: Brieven en Papieren van Guinea aan de Kamer van Amsterdam - W.I. C., No. 488, fol. 749r. 
kunnen, dan met blanken niet souden mogen calachaeren ${ }^{1}$ ), en dat wel, omdat se weeten, dat in het vaderland een dusdaenig houwelijk on de religie niet werde gedult". Zoo bestond zijn school dan voornamelijk uit jongens, die als slaven of vrïen bij de blanken werkten, twee blanke kinderen, die uit Holland gekomen waren, twee tapoejerinnetjes, en nog een tapoejerinnetje met haar slavinnetje.

Was het getal scholieren niet groot, over hunne vorderingen was Capitein, blijkens zijn verslag, wel tevreden. Door een klein geschenk was hun jiver te wekken. Hun

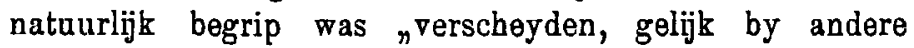
rolkeren". De meesten waren in die vijf maanden tijds het A.B.C.-boek reeds door, maakten goede rorderingen in de spelkonst, terwïl sommigen reeds het "Gebed des Heeren" konden opzeggen on nu tot het leeren van de "Twaalf Artikelen" en de „Tien Geboden" overgingen. De resultaten waren dus aanvankelijk niet onbevredigend. De Satan trachtte het werk wel af te breken, maar aangaande de vervulling van Gods beloften in zake de roeping der heidenen, meent hij wel twijfelmoedig, doch niet mismoedig te mogen zijn. Als ideaal staat hem voor oogen, om nog eehs twee of drie.van deze zwarte kinderen, met goedvinden van den directeur-generaal en hunne ouders, naar Nederland over te zenden, om daar de studiën voort te zetten. Reeds denkt hij er over, om de Neger-taal in geschrift te brengen; of die taal echter ${ }_{n}$ in alle haer deel konne uytgedrukt worden" had de ondervinding echter nog niet geleerd. Over één punt vraagt hij aan de Bewindbebberen nog om voorlichting - een vraag, die toch eigenlijk bij de classis van Amsterdam thuis behoorde-, namelijk : of hij de heidenkinderen zou doopen wanneer zij bet "Onze Vader", de "Twaalf Artikelen" en de "Tien Geboden" kenden en verstonden, dan wel dat hij zou wachten tot $2 \ddot{j}$ volledige belijdenis des geloofs hadden afgelegd.

Deze beschrijving van de Kerk- en Schoul-staat van

1) Zie hiervóòr, blz. 217. 
St. George D'Elmina, werd behalve door Capitein ook nog doór de beide ouderlingen Antonius van Lokhorst en J. Romejn onderteekend.

De Bewindhebberen hebben dit verslag voor notificatie aaugenomen en in ruim een jaar tijds op de daaringestelde rraag geen antwoord gezonden, waarover Capitein zich herhaaldelijk beklaagt. Eindelijk kreeg hij van hen 2 October 1744 een brief, waarin zij. zegden met genoegen vernomen te hebben over "sijn iever en aengewende devoiren niet alleen tot onderwysinge van de aldaar sïnde christenen, maar ook om de verblinde heydenen te brengen tot de kennisse van den waare God". Inzake de gestelde vraag merken zij op: „WJ kunnen ons niet precise inlaten omtrend den doop van de kinderen der heydenen en in hoeverre zy moeten zijn onderweesen in de gronden van de christelyke godsdienst, voordat aan haar het sacrement van den doop werde bedient; en vermits aan UEd. bekent zijn, de kerkenordres omtrend den doop, zoo zult UEd. met betrekkinge tot den doop van de kinderen der heydenen moeten handelen, zooals UEd. amptshalren en in goede gemoede zult berinden meest nodig en dienstig te zijn, tot voortplantinge der christelycke religie onder de heydenen" 1). Capitein was dus nog eren wijs gebleven als tevoren. Ook in den brief der Bewindhebberen aan Capitein dd. 9 Mei $1746^{\circ}$ wordt gezegd, dat mon de regeling dezer dingen aan hem overliet. Als het noodig was een "queekschool off weeshuys" te stichten, dan moest Capitein hierover maar met den directeur-generaal overleggen ${ }^{2}$ ).

Zorgde Capitein zoo voor het onderwijs der kinderen, de Bewindhebberen stuurden de leermiddelen: A. B. C. boeken, "kinderonderwysingen", bijbelprenten, ja ook een

1) Brieven naar Guinea van de Thienon - W.I.C., No. 57, fol. bi4v (2 Oct. 1744). In de Resolutien van de Vergadering der Thienen (15 Sept. 1744) - W.I.C., No. 11, fol. 144r-1 werd tot het zenden van dezen brief besloten.

2) Brieven naar Guinea van de Thienen - W.I.C., $\mathrm{N}^{\prime \prime} .57$, fol. $69 \mathrm{r}$ (9 Mei 1746). 
stukje liminnias - een soort katoen of laken - ter goede "bestuuringe, onderwysinge en aenmoediginge" der neger- en tapoejerkinderen ${ }^{1}$ ). Doch ook zijne eigen studiën verwaarloosde hij niet. Op 15 Februari 1743 berichtte De Petersen, dat hï de boeken, die de Bewindhebberen voor Capitein ingekocht hadden, aan dezen had ter hand gesteld. Het lijstje van nieuwe boeken, die Capitein gaarne zou hebben, werd tegelïkertïd overgezonden. Op deze "Petitie van Boeken" stond: „1. Acta Synodalia; 2. Salomon van Til, Voorhor der Heydenen; 3. Eusebii, Praeparatio et demonstratio erangelica; 4. Spanhemii; dubia Evangelica; 5. Westhovii, in Passionem; 6. Polisynopsis; 7. Rabbi David Kimchius, vel R. Salomon Jarchi, in Vetus Testamentum; 8. Opera Ainsworth", titels die de richting zijner studiën aanwijzen 2). De taal en stïl zijner brieven is vrij goed, al is die niet onberispelijk. In plaats van de "f" gebruikt hij dikwïls een ${ }_{n}{ }^{\prime \prime}$ (schrij $\nabla t$ i. p. $\nabla$. schrijft), en eens spreekt bij van de Compagnie als van de "aloude en alom b e r u g t e Maetschappy", wat hij in dien minder gunstigen zin zeker niet zoo bedoelt 3 ). Tot meerdere glorie had hij zich ook een zegelring aangeschaft, waarmede een van zijne brieven verzegeld is 4).

In het volgende jaar 1744 is hij over de belangstelling ran de bewoners $\operatorname{van}$ het Hoofdkasteel toch eigenlijk minder goed te spreken. Hij had al wat in zijn vermogen was gedaan, om de kinderen naar school te lokken, maar geen gehoor gevonden. $\mathrm{Nu}$ had hij het op eene andere inanier geprobeerd. Bï het Hoofdkasteel behoorde het negerdorp - in der zwarten taal "crom" gebeeten - en bierheen had hij zich begeren, om met de "Grandes", de opperhoofden, te spreken, ten einde hun het doelwit der Bewindhebberen te openbaren, namelijk

1) Bijlage V (25 Nov. 1743), blz. 256.

2) Brieven en Papieren van Guinea aan de Kàmer van Amsterdam W. I. C., No. 488 , fol. 790 r.

3) Bijlage VI (28 Apr. 1744), blz. 258.

4) Bijlage IV (18 Apr. 1743), blz. 255. 
dat deze "Grandes" met hunne kinderen Christenen zouden worden; zij waren nu verplicht $n^{\text {aen }}$ hetselve doelwit, sonder langer uytstel, als wettige onderhoorige" der Bewindhebberen te roldoen. De opperhoofden luisterden met welgevallen naar zijne woorden en beloofden niet alleen hunne eigen kinderen, maar ook die hunner nabestaanden bij Capitein op school te zullen zenden. Zoo waren er dan nu 45 gekomen, van wie hij nog wel niet veel zeggen kon - alle begin was immers moeiläk - maar die toch aanvankelïk betere hope gaven, dan de kinderen van het Hoofdkasteel ${ }^{1}$ ).

Het gerucht van Capitein's werkzaamheid drong door tot den koning van de naburige negerstam der Ashantijnen, met name Pokoe. Aangelokt door de goede resultaten, welke men met Capitein in Nederland had verkregen en die men thans door zijnen arbeid te St. George D'Elmina bekroond zag, zond Pokoe op zekeren dag twaalf negerjongens en twee negermeisjes naar den directeurgeneraal De Petersen met het verzoek, om deze naar Holland over te sturen, ten einde ze daar "te laaten leeren leesen, schryven en in de musicq onderwysen". De verstandige, naar verlichting dorstende vorst, begreep heel goed, dat dit met onkosten zou gepaard gaan, waarom hij hun tien olifantstanden medegaf, om uit de opbrengst de studiekosten te dekken. De directeurgeneraal De Petersen zag, op zijn beurt, echter wel in, dat de Bewindhebberen met dit stel van veertien negerkinderen danig verlegen zouden zitten, berichtte dus aan Pokoe, dat dit niet zou gaan, maar dat hij de kinderen bij Capitein op school zou doen. De koning nam hiermede genoegen; de kinderen $k$ wamen bij Capitein op school en bij de negerin Coffiba in de kost, die ultimo Juni 1744 voor het onderhoud 1 peso ontring ${ }^{2}$ ). Pokoe verzocht

1) Bijlage IV (18 April 1743), blz. 254.

2) Extract uit: "Het Groot Handelboek over de Noord- en Zuydkuste van Africn van den jaaren 1744" in : Brieven en Papieren van . Guinea aan de Kamer van Amsterdam - W.I.C., No. 489, fol. 537r. - 
echter wel dringend, dat hem dan zou worden toegestaan, om die tien olifantstanden, onder opzicht van een neger op een Compagnies-schip overgezonden, als een geschenk aan de Bewindhebberen te mogen "offereeren".

Daarbij had de negervorst dan nog een varigen, doch voor onze ooren zonderlingen wensch: hij zou gaarne willen hebben ${ }_{n}$ een doodkist met glaase vensters of schuyven booven aan het hoofdenend, en op beyde de zyden", dan zou men hem, na zijn overlïden, in volle tooi en met reel gouden opsmuk in zijn. kist gelegd, natuurlïk van alle kanten kunnen bekijken ${ }^{1}$ ). De Petersen, begrijpende, dat deze zwarte vorst de Hollandsche natie veel voordeel kon aanbrengen maar ook door het sluiten der grenzen veel nadeel berokkenen, en "dat de maadschappy ten opsigte $\nabla a n$ de recognitio van den slaafschen handel daarby wel het meeste geïntresseert" was, bewilligde in beide wenschen van Pokoe. Een negerjongen Jacje werd dus met ${ }_{n}$ de Maria Galey" naar Nederland gezonden, om de tien tanden den Bewindhebberen aan te bieden; de doodkist liet $\mathrm{De}$ Pełersen voor eigen rekening bij zijne correspondenten Lohoff en Gebrs. Ploots van Amstel te Amsterdam ontbieden, „omdat - zoo schrijft bij - (ik) selfs daarby eenigsints geintresseert ben" ${ }^{2}$ ).

De Bewindhebberen hebben de tien olifantstanden dankbaar aanvaard en keurden goed, dat de doodkist, welke De Petersen had besteld, zonder betaling van vracht, met hèt eerstrertrekkende Compagnies-schip zou worden osergezonden. $\mathrm{D}_{\boldsymbol{\theta}}$ matregelen door $\mathrm{De}$ Petersen getroffen

Een peso vertegenwoordigt de waarde van 8 a 10 gld. Zie: Beschryvinghe ende historische verhael van het Gout Koninckrijck van Gunea, door P. de Marees, uitgeg. door S. P. L'Honoré Naber (Linschoten-Vereen., DI. V), 's-Grav. 1912, blz, 280.

1) Zie hoe Kwakoe Dua, de koning van Ashantijn, 28 April 1867, te pronk ligt: C. A. Jeekel, Onze bezittingen op de kust van Guinea", Amst. 1869, blx. 40, aant. (*).

2) Bijlage VII (1 Mei 1744). Op 29 April 1744 verklaarde kapitein Christiaan Velts de tien olifantstanden, gemerkt $W$; in zijn schip ontvangen te hebben. Brieven en Papieren van Guinea aan de Kamer van Amsterdam - W.I. C., N0. 489, fol. 100. 
in zake deze negerkinderen, hadden gebeel de instemming der Bewindhebberen; die kinderen zouden voor de Compagnie niet alleen "een swaare last" zijn geweest, maar het zou ook "seer difficiel" zijn geweest, om in Nederland iemand te vinden, die over ben opzicht zou kunnen en willen houden ${ }^{1}$ ). Ook later nog zonden de Bewindhebberen voor dezen Ashantijnschen koning Pokoe, die om zijne goede verstandhouding met de Compagnie, de jalousie van de naburige stammen opwekte, eenige geschenken als: een rijtuig en een windroer, welke $\mathrm{De}$ Petersen beloofde in naam van de Compagnie te zullen aanbieden "met byroeginge ran sodaanige harangue, als met de genies ende gewoontens van de Naturellen overeenkomt" 2 ).

Zoo ging dus aanvankelijk alles goed. Capitein arbeidde niet ongezegend, inzonderheid onder de negerkinderen; deze arbeid werkte zelfs suggestief op den Ashantïnschen vorst Pokoe, en de directeur-generaal De Petersen prees den j̈ver van den predikant in de rolgende bewoordingen: „ick niet wel met stilswygen kan voorbygaan, dat ick dagelïks oor- en oog-getuygen ben van den onophoudelyken iver, die zijn-Eerwaarde, den heere predicant voornoemt, aanwend, omme waar het mogelijk, het heylsaam oogmerk te berey.ken, en ten dien eynde de kinderen van de Naturellen so veel als doenlijk is de beginselen van de ware christelyke religie doet inboesemen" ${ }^{3}$ ).

Doch toen gebeurde er iets, waardoor Capitein's aanzien in St. George D'Elmina verminderde, en dat, naar het mij voorkont, een van de hoofdoorzaken is geweest, waardoor zijn arbeid met lambeid werd geslagen.

1) Missive van de Bewindh. aan dir. gen. De Petersen (2 Oct. 1744)

in : Brieven naar Guinea van de Thienen - W. I.C., N0.57, fol. 69.

2) Brieven en Papieren van de kust van Guinea aan de Kamer van Amsterdam - W.I. C., No. 489, fol. 366" (20 Mei 1746).

3) Missive van dir. gen. De Petersen aan de Bewoindh. der W. I. C. (15 Aug. 1743) in : Brieven en Papieren van Guinea aan de Kamer van Amsterdam - W.I. C., No. 489, fol. 81 ${ }^{\mathrm{r}-\text { ". }}$ 
$\S 4$.

Capiteirn's wrRkzaAmHetd te St. George D'Elmina. Verval.

Amor kwam in het spel. Capitein sloeg een welgevallig oog op een zwart heidinnetje en wilde haar huwen. $\mathrm{H}_{i j}$ heeft ons zelf de geschiedenis zijner liefde uitroerig medegedeeld, en wil ons daarin aannemelijk maken, dat hij met eene jonge negerin wilde trouwen, om zijn oogmerk - de bekeering der heidenen — des te eerder te bereiken en het vertrouwen en de genegenbeid der negers voor zich te winnen, $n^{\text {als }}$ die dan souden konnen sien, dat hoewel ik van hun in leevensmanier en in godsdienst verschille, sy evenwel van my niet veragt worden". Ook wenschte hij te huwen, om zich te bewaren en te wapenen tegen "de verlydingen des Satans". Toen Capitein nu de voor hem geschikte negerin, naar hij meende, geronden had en den directeur-generaal on de ouderlingen hiervan in kennis stelde, werd de vraag geopperd, of Capitein haar wel eerst huwen en pas daarna in den christelijken godsdienst onderwijzen mocht. Het "Groot Plakkaatboek" van hunne Edelmogenden werd opgeslagen, en daaruit duidelijk verstaan, dat de heidin eerst behoorde onderwezen en gedoopt te worden, alrorens zij Capitein's wettige vrouw zou kunnen worden. Thans was echter de noeilijkheid, hoe dit onderwijs in te richten, opdat geen opspraak zou worden verwekt. Dit zelf te doen, ging voor Capitein bezwaarlijk; den voorlezer en schoolmeester Adrianus van Waghem wilde bij haar ook niet toevertrouwen, en eene Hollandsche vrouw, die haar eene christelijke oproeding kon geven, was er niet. Het beste zou dus zijn, om haar naar Nederland te zenden; doch dit weigerden op hunne beurt hare ouders, zeggende dat $z i j$ wel toestemming wilden verleenen, wanneer Capitein haar aan het Hoofdkasteel wilde trouwen en "tot Christen maken". Capitein vroeg nu om raad aan de Bewindheb-

XIII. 
beren 1), doch kon reeds 18 April 1743 berichten, dat zij nu bij hem, met nog andere negerinnen en tapoejerinnen, op school was, om zoo op een wettige wyse tot (s)ịn oogmerk bequaem gemaekt (te) worden" 2).

Inmiddels was dit voornemen van Capitein ter oore gekomen aan de classis van Amsterdam, waarbij nog als verzwarende omstandigheid gold, dat naar men hoorde, Capitein de vrouw ook als heídin had willen huwen, dat hem dit door den directeur-generaal De Petersen was belet, waarom Capitein dezen had aangeklaagd. De classis, die toch al niet te best over Capitein te spreken was, omdat hij, tegen zijne belofte in, nog niets van zich had laten hooren, vertoornde. In de vergadering van $12 \mathrm{Ja}$-. nuari 1745 werd besloten, om den ndeputati ad res exteras" op te dragen, Capitein de verwondering der classis, dat hij nog niet geschreven had, als ook haar ernstig misnoegen, kenbaar te maken 3). Toen dit besluit genomen werd lag de brief dd. 10 Januari 1745 al gereed, waarin de deputati hem over zïne slechte correspondentie onderbielden en hem deden weten, dat Capitein's gedrag onbehoorlijk was. Een dergelijk huwelijk verbood God toch zoo duidelïk en volstrekt mogelijk aan Israël, en de Apostel Paulus leerde, dat men hetzelfde juk niet moest aantrekken met een ongeloovige: "die trouwt, trouwe in den Heere". En de classis vervolgde: n't Komt de F. classis desweegen so roor, dat UEerw. een van beide (sig bepaelt hebbende tot huwelyke) - te doen hebbe, of naar yemant omme te sien, die dienselve Naeme aenroepe met UEerw., of deese, die UEerw. in 't oog heeft, of gehad heeft, eerst tragte te gewinnen, so het mogelijk was tot het gelore en ongereinsde bekeringe; de classis versoekt dan, dat UEerw. des aangaande eens weder berigt aan haar E., so ras mogelijk is, toesende, en dat UEerw., behalven de reedenen boven gemeldt, indagtig

1) Bijlage II (15 Febr. 1743).

2) Bijlage IV (18 April 1743), blz. 254 .

3). Acta Classis Amstelodamensis, XII, fol. 80-81. 
sijn moogt, dat gy met oplegginge der handen tot een voorganger in de gemeynte sijt aangestelt geworden" 1 ).

Door dezen alles behalven vriendelijken brief en de oppositie in St. George D'Elmina zelf, heeft Capitein zijn plan om deze heidin te huwen laten varen. Op het schrijven van de classis antroordt hij 21 Mei 1746 met de mededeeling, dat hij geen correspondentie met de classis beeft gevoerd, ten eerste, omdat in zijne instructie stond, dat bij "den staet, stand ende gelegenheyd van saeken, raekende de religie" aan de Bewindhebberen had te be-. richten, hetgeen hij ook gedaan had; ten tweede was er nog geen geordende gemeente, en ten derde meende hij dat de classis met de Compagnie wel onderling overleg plegen zoude. Doch op het uitvoerig verslag van Kerken School-staat had hï geen enkel bericht terug ontrangen; hij had er dus verder maar niet meer over geschreven, want door de verstrekte mededeelingen had hij zich toch al een openbaren en onverzoenlijken hat van velen op de Goudkust op den hals gehaald. Wat nu zijn huwelijk met de negerin betrof: het was inderdaad „eene groote onderneeming", maar onbedachtzaamheid was het niet, hetgeen hij met vele redenen zou kunnen betoogen, maar dat overbodig zou zïn, nu de alleenwïze God, die alles roorziet, hem met het laatst uitgekomen en nu repatriëerend Compagnies-schip eene Europeesche christen-jongedochter had beschikt 2). Deze heette Antonia Ginderdros, geboren te 's-Gravenhage, en was onder het opzicht van het huisgezin van Jan Credo Bacot overgekomen ${ }^{3}$ ). Op den 3 den October 1745 was orer hen beiden de eerste huwelijksproclamatie afgekondigd, en op den 10 den October d.a. v. de tweede en derde, terwijl op dienzelfden

1) Missive van de Classis van Amsterdam aan J. E. J. Capitein (10 Jan. 1745), in: Acta Classis Amstelodamensis, XXX, Briefnummer 18.

2) Bijlage X (21 Mei 1746), blz. 268-270.

3) Bijlage XI (23 Mei 1746), blz 275. In De Navorscher, Jaarg. 27 (1877), blz. 49, 50 staat abusievelijk "Gendẹrdros". 
dag het huwelijk meteen was voltrokken 1). De directeurgeneraal had ter eere van het jeugdige paar een feest gegeven. Dit buwellijk werd spoedig door een tweede gevolgd: de assistent Pieter Hugo Coene buwde met juffr. Susanna de Jonge, zoodat er toen in het geheel zes wettig gehuwde personen op St. George D'Elmina woonden, onder wie ook was een zekere Jacob Cau, neef ran den "nooyt volpreesen Herm. Boerhave". Uit deze gezinnen hoopte Capitein weldra de vakant geworden ouderling-plaatsen te kunnen bezetten 2 ).

Zoo was dan nu wat Capitein persoonlijk aanging de vraag ọver een huwelijk van een christen met eene heidin opgelost, doch de kwestie bleef toch evengoed bestaan, weshalve Capitein haar ter oplossing voor de classis van Amsterdam bracht. Indien nu eens negerjongens - aldus redeneerde hij - die onderwezen waren, gedoopt en lidmaten waren geworden "om sig te bewaeren voor den ontugtigen wandel van 't heydendom" wilden huwen, wat moest men hun dan raden? Europeesche christenmeisjes konden zij niet tot vrouw nemen "omdat bet niet denkelijk $z y$, dat er hier ligtelijk eene volkplanting sal weesen". Met negermeisjes huwen, die Christin waren geworden, ging ook niet, want die waren er niet; de negerouders toch lieten wel hunne jongens in den christelïken godsdienst onderwijzen, maar do meisjes niet, omdat zij deze liever bewaarden als bijzitten voor de Cbristenen, die in leer en leven afweken. En zulke bijzitten werden er vele gevonden, „die - schrijft Capitein niet alleen boven den predikant en koster geliert zijn, maer ook meerdere inkomsten hebben dan die beyden". Wat moest men dus bijr. aan een soldaat, die niet wilde "calacharen", doch een wettig buwelijk met negerin of tapoejerin wilde sluiten, raden? 3 )

1) De Navorscher, Jaarg. 27 (1877), blz. 49-52.

2) Bijlage XI (23 Mei 174(i), blz. 275. De onderlingen Antonius van Lokhorst en Jin Romeyn waren overleden.

3) Bijlage X (21 Mei 1746), blz. 270-271. 
De classis van Amsterdam zond hierop 3 October 1746 eene missive aan Capitein, waarin zij zich over de gunstige wending in zijne huwelijksplannen verheugde en hem op de gestelde vragen het volgende antwoord gaf:

"10. Dat gene dispensatie kan gelden tegen het uitdrukkelik apostolisch bevel: ,trekt niet een ander jok aan met de ongelorige 2 Cor. $6: 14^{\prime}$;

$2^{0}$. Dat UEerw. alle naarstigheid hebbe toe te brengen, on ook negerinnen en tapoejerinnen tot bekeringe to bewegen, en daartoe naarstig te onderwyzen;

$3^{0}$. De christenen te vermanen, dat sy hun vat soeken te besitten in heiligmakinge en eere" ${ }^{1}$ ).

Wij zagen reeds, dat Capitein al spoedig het roornemen had opgerat, om eenige geloofsstukken in de Negertaal over te brengen ${ }^{2}$ ). Hij verstond deze taal van kindsbeen af, en deed ook soms dienst als tolk, wanneer er met de "Hommes Grandes" van het ${ }_{n}$ crom" of zelfs wel, als er met de "Caboceërs" (opperhoofden) onderhandeld werd ${ }^{3}$ ). Dit plan heeft hij ten uitroer gebracht, want 15 Augnstus 1743 schrijft directeur-generaal $\mathrm{De}$ Petersen aan de Bewindhebberen, dat hij de eer had hun toe te zenden "het $\nabla$ ader ons, de Tien Gebooden en het Gelooff, overgebragt in de negerstaale, met gedienstig versoek uyt de naame van den heer predicant alhier", dat, indien dit werk aan de Bewindhebberen behagen mocht, zij het zouden ter hand stellen aan den theologischen candidaat Hiëronymus de Wilhem, om bet voor de drukpers gereed te maken ${ }^{4}$ ).

Deze vertaling schijnt den heeren Bewindhebberen niet onwelkom te zijn geweest, want zij werd gedrukt. Een exemplaar van dit thans uiterst zeldzaam geworden

1) Missive van de Classis van Amsterdam aan J. E. J. Capitein (3 Oct. 1746), in : Acta Classis Amstelodamensis, XXX, Briefnummer 35.

2) Zie hiervóór, blz. 219 .

3) Brieven en Papieren van Guinea aan de Kamer van'Amsterdam W. I. C., No. 489, fol. 272r-275" (3 Sept. 1744).

4) Brieven en Pupieren van Guinea aan de Kamer van Amsterdam W. I. C., No. 489, fol, 81r-r (15 Aug. 17.'3). 
boekje heb ik kunnen opsporen. Het is een octaro-drukje, 20 blz. groot en af komstig uit de bekende Duncan-collectie, berustende op de Koninklijke Bibliotheek te 's-Gravenbage 1). In de "Voorreden tot den Christen Leser" zegt Capitein betreffende de samenstelling van dit werkje het volgende: „Zie hier, Beminde Christen Leser $\mid$ bet allereerste beginsel, dat wy maaken, tot de eerste en tedere Grondlegging des Christendoms, onder onze Negeren Tapoejer-Schoolkinderen, aan het Hoofd-Casteel der Generaale Geoctroyeerde Nederlandsche West-Indische Compagnie, St. George d'Elmina. Denk geensins, dat deze Vertaaling (die nu meerendeels geschied, om te verneemen, of deze Taal in haar geheel schryfbaar zy) volmakkt uitkome, maar dat dezelve, zo God ons eene meer geopende deur zal gegeren hebben, in verrolg van

1) De titel van het boekje is: Vertualing van het Onze Vader, de Twoalf Geloofs-Artykelen, en de Tien Geboden des Heeren, Uit de Nederduitsche Taal, in de Negersche Spraak, zo als die gebruikelij! is van Abrowarie tot Apam, Doorgaans Letterlyk overgebragt door Jacobus Elisa Joannes Capiters, Predikant op d'Elmina. Op zijn Eerw. versoek uitgegeven door $\mathrm{Hi}$ ieronymus de Wilhem. Te Leyden, By Jacobus de Beunje, 1744. $8^{0}(151 / 2 \times 91 / 2)$. Op blz. 2 : Zephanja III : 9, 10 voluit weergegeven; blz. 3-4: „Voorreden tot den Christen Leser", gedateerd "Op d'Elmina, den 3 Augustus 1743"; blz. 5-7: „De uitgever aan den Leser"; blz. 8: Het Onze Vader in de Negertaal; biz. 9: Het Onzer Aller Vader in de Nederlandsche taal d. w. z. de vertaling uit de Negertaal in het Nederlandsch; blz 10 en 12: De Geloofsartikelen in de Negertaal; blz. 11 en 13: Het Geloof in de Ned. taal d.w.z. de vertaling uit de Negertaal in het Nederlandsch; blz. 14, 16 en $18:$ De Tien Geboden in de Negertaal; blz. 15, 17 en 19: De Tien Woorden Gods in de Ned. taal d. w. z. in de vertaling uit de Negertaal in het Nederlandsch; blz. 20 : in blanco. Men vergelijke ook: H. van Cappelle, Surinaamsche Negervertellingen, $B i j-$ drage tot de kennis van West-Indische negerfolklore, in: Bijdragen tot de Taal-, Land- en Volkenkunde van Nederlandsch-Indië, Deel 72 (1916), blz. 233-379 en de daar genoemde literatuur. De negers van Suriname kwamen voor het meerendeel van de Goudkust. - Ik mag deze zanteekening niet besluiten, zonder een woord van uitnemenden dank gebracht te hebben aan de ambtenaren der Koninklijke Bibliotheek te 's-Gravenhage, inzonderheid zan den heer A. J. de Mare, voor de eindelooze nasporingen in de bibliotheek ingesteld, om dit nog niet gecatalogiseerde pamfletje terug te vinden. 
tijd beschaafder worden zal. Vaar Wel!" Deze voorrede is onderteekend door: "Jacobus Elisa Joannes Capitein, Predicant op d'Elmina" en gedateerd: „Op d'Elmina, den 3 Augustus 1743".

Ook de uitgever wendt zich tot den lezer met eene mededeeling. Het is hem opgevallen, dat blïkbaar begrippen als „eeuwigheid" - "eeuwig leeven" en „heilig" in de Negertaal niet kunnen worden uitgedrukt. En daar in het tiende gebod, in plaats van "ezel" - "een paard" is gesteld, zoo gist de uitgever ",dat het Vaderland van den Eerw. Overzetter met die langgeoorde dieren niet voorzien is". "Het onzer Aller Vader", alsmede de zesde bede „En leid ons hoofd niet tot het quaade, opdat ons ook geen ander quaad doe" heeft hem getroffen, doch bovenal wil de uitgever des lezers aandacht vestigen op het vierde gebod; waar de woorden "nog uw dienstknegt" in de vertaling, blijkens de Nederlandsche tekst, welke er naast gedrukt staat, ontbreken. En toch bestaat het woord "dienstknegt" in de Negertaal wel, omdat het in het tiende gebod is gebruikt. De uitgever wil het hieraan toeschrïven, dat het bij ongeluk is overgeslagen; doch waar de schrijver niet is te raadplegen en niemand in Holland de Negertaal kent, zoo moet men wel in onzekerheid blïren. Misschien heeft de uitgever gelijk, en is dit wel inderdaad eene vergissing geweest, doch het zoude ons niet verwonderen, als Capitein, die om bij de Bewindhebberen in bet gevlei te komen de slavernij verdedigde, ook hier met opzet de "dienstknechten" heeft weggelaten, uit vreeze dat de Naturellen dit gebod eens tegen hunne meesters zouden uitspelen.

Op de tegenover elkander geplaatste bladzijden vindt men nu telkens op de eene het Onze Vader, de Geloofsartikelen en de Tien Geboden in de Negertaal, en op die daartegenover de hieraan beantwoordende Nederlandsche overzetting. Capitein is dus begonnen adaequate voorstellingen te zoeken, heeft de geloofsstukken dien overeenkomstig opgesteld, doch slaagde er niet in, ze steeds volkomen zuiver uit te drukken. De uitgever wees reeds 
sommige afwijkingen aan. Ook ons treft het bijroorbeeld, dat hij in plaats van "heiligen", ons begrip "goeden" weergeeft; inplaats $\operatorname{van}$ "en een eeuwig leven" - „ende dat God hen altijd wel bewaren zal" uitdrukt. In de Tien Geboden wordt het vierde gebod aldus aangevangen : "Gedenkt den Zondag, dat gy God dient". De moeilijkbeid van overzetting in de taal der primitieven, heeft dus Capitein reeds geroeld.

Op ésn punt willen wij nog de aandacht vestigen, namelijk dat het woord voor "God" hier steeds is "Jancómpon" d.w.z. Jan Compagnie 1), een niet geheel onbekend verschijnsel, waarbij de opmerking terecht gemaakt

1) Dat de naam van het Opperwezen : "Jancómpon" of "Jan Compaan", met Jan Compagnie in verband staat, is niet geheel zeker. J. J. Hartsinck, Beschryving van Guiana of de Wilde kust in Zuid-America, Alnst. 1770, DI. II, blz. 902 zegt hierover: „Sommigen hunner (nml. der negers) verbeelden zich, dat de Menschen door een groote Spin, dien zij Aransié noemen, zijjn greschapen: anderen dat God, bij hen Jan Compaian genaamd, en voor een goed Man gehouden, zwarten en blanken Menschen te gelijk heeft roortgebragt; dat de Zwarten hadden verkooren de gaave en bezitting van het Goud, en de Blanken die der Kunsten en Wetenschappen, waarom de eerstgemelden de laatstgenoemden ten eeuwigen dagen moeten dienen". In de Beschryvinghe ende historische verhael van het Gout Kominckryck van Gunea, anders de Gout-custe de Mina genaemt, liggende in het deel van Africa, door P. de Marees, uitgeg. door S. P. L'Honoré Naber, 's-Grav. 1912 (Werken uitgeg. door de Linschoten-vereeniging, No. 5), blz. 75, wordt gezegd: „ende omdat sy ( $\mathrm{nml}$. de negers) wel weten dat onse Heere Godt boven in den Hemel woont, soo als het dondert ende blixemt soo wysen sy om hooch ende noemen hem Iuan goemain". Naber teekent hierbij aan: "Latere Hollandsche schrijvers hebben daarvan gemaakt: Jan Compan (Compagnie), en geven daarvan dan eene voor de hand liggende afleiding". Hij waagt de veronderstelling, dat het geheele begrip slechts aan de negers gesuggereerd is, in dien zin, dat het westersch begrip "Opperwezen" in een negertaal werd overgezet door Nyanktipon (the great Friend) en dan bij navraag eenvoudig werd teruggekaatst". Maar het is toch, onzes inziens, on waarschijnlijk, dat de inboorling Capitein, no $\tau$ wel in een onderwijsboekje voor inboorlingen, zich met een klanknabootsend woord zou hebben tevreden gesteld. Inderdaad lijkt het hier medegedeelde het gevoelen te versterken, dat er tusschen het neger-begrip voor "Opperwezen" en „Jan Compagnie" mogelijk eenig verband bestaat, hetgeen Capitein niet zal hebben betreurd. 
is, dat de Compagnie haar naam dan toch geleend zou hebben niet aan een boozen maar aan een goeden geest 1 ).

Het geschrift was dan nu in druk uitgegeren, maar Capitein had het buiten weten of approbatie van de classis ran Amsterdam om gedaan, en deze liet niet na hierover haar ernstig misnoegen in den reeds aangehaalden brief dd. 10 Januari 1745 te kennen te geven.

De classis had een exemplaar van dit boekje onder de oogen gekregen; zï prees weliswaar de goode bedoeling, om dio stukken der waarbeid ook voor de negers in hunne eigen taal toegankelijk te maken, maar zij had toch - met den uitgever, blïkens diens voorbericht - eenige belangrijke bedenkingen. Capitein had in de eerste bede van het "Onze Vader" vertaald: „Onser a ll er Vaeder, die in de bemelen sijt" " $)$. Dit stond noch in het oorspronkelijke Grieksch, noch in eenige andere Europeesche vertaling, maar de classis wilde zich geen oordeel aanmatigen, omdat zij de Negertaal niet kende. Van ernstiger aard vond de classis, dat Capitein in bet vierde gebod van de „Tien Geboden” had uitgelaten, dat ook de die nst$\mathrm{k} n \mathrm{ech}$ te $\mathrm{n}$ moesten rusten op den sabbathdag. Het gebeele blad moest dus herdrukt worden; met deze uitlating mocht het niet in omloop worden gebracht. Voortaan moest Capitein ook, alvorens hij iets uitgaf, zich van de approbatie der classis verzekeren. Over het een en ander wilde de classis van hem nog wel eenige "elucidatie" ontrangen ${ }^{3}$ ).

Deze opheldering heeft Capitein haar verschaft in eene missive d.d. 21 Mei 1746. Capitein had de kopij niet aan de classis ter approbatio gezonden, omdat h $\ddot{j}$ meende, dat de vergadering der Thienen en de classis onderling wel connectie hielden. De "misslagen" in zijne vertaling had hij opgemerkt; bij de eerste gelegenheid zou hij de ver-

1) Encyclopaedie van Ned. West-Indië, 's-Grav.,-Leiden 1914, blz. 391.

2) Eigeulijk staat er: „Onzer aller Vader, die in de Hoogte zijk".

3) Missive van de Classis van Amsterdam aan J. E. J. Capitein (10 Jan. 1745), in : Acta Classis Amstelodamensis, XXX, Briefnummer 18. 
betering roor den herdruk van het blad overzenden. Daarbij zou hij dan de kopij der vertaling van Jacobus Borstius' "Kindercatechismus" voegen, welke hij voor de pers in gereedheid had 1). Aan de Bewindhebberen berichtte de slimme vogel, echter níet, dat de classis aanmerkingen had gemaakt, doch dat ,het opgewekter begrip, dat ik thans ran onse negerspraek verkregen hebbe, heeft my doen opmerken, dat deese vertaeling eenjge beschaeving vereysche". Intusschen liet hä, om geen tïd te verliezen, de kinderen er maar al vast uit leeren 2).

Werd Capitein zoo in allerlei moeilijkheden gewikkeld, met zijue prediking had hij ook geen succes: Hij miste den slag om de kolonisten - dat wondere volkje - te boeien. De catechisatie, welke hij in de week hield, verliep, en toen hij haar daarna nog eens instelde, moest hij haar uit gebrek aan belangstelling wederom sluiten. Het is waar, dat de verplaatsing der leden naar de buitenforten en de groote verscheidenheid van gezindheden ook hiervan mede de oorzaak waren, doch Capitein begint te klagen over eene groote lusteloosheid bij velen tot den dienst des Heeren. „Was er - aldus in een brief d.d. 23 Mei 1746 - een openbaer en uytdrukkelijk gebod van dat soo niet allen, tenminsten de Gererormeerde Christenen onder ons, die nog geene ledemaeten zijn, soolang sy hier in't Hoofd Casteel olyren, gehouden waren, om eens ter weeke by den predikant te komen catechiseeren, dan soude dit werk mogelijk eenigen voortgang bebben; want was het met den openbaeren kerkgang soo niet gelegen, soo souden er seer weynigen - de goeden uytgenoomen - doorgaens te kerke komen" 3).

Het kerkelijk leven had nooit te St. George D'Elmina gebloeid, hetgeen hij met de stukken zou kunnen bewijzen. En wat den meesten zïner roorgangeren was ten deel gevallen, zou ook hem, naar hij meende, wedervaren nml.

1) Bijlage X (21 Mel 1746), biz. $271 ; 262$.

2) Bijlage XI (23 Mei 1746), blz. 274.

3) Bijlage XI (23 Mei 1746), blz. 274. 
„dat sy sonder rrugt hebben moeten arbeyden en hunne kragten doorbrengen, en by de meeste Christenen alhier, die in zeden verdorven zijn, gehaet, veragt, belaegt en vervolgt, hunnen dienst hebben moeten pleegen". Capitein had, bij een nauwkeurig onderzoek naar de "kerkelyke schrivten deeser kuste", een Kerk- en Doop-boek geronden, dat reeds in 1683 was aangelegd, doch eigenlijk geene andere notulen bevatte, dan die van zïnen voorganger Isaacus Ketelanus. Een naamlijst van predikanten was er niet in te vinden; kerkelijke zaken kwamen er geene of weinige in roor. En die er dan nog in stonden waren van lasterlijken aard. Zoo was er, door den president F. Barovius betreffende den directeur-generaal Fr. de Bordes, die ouderling was geweest, aangeteekend, dat De Bordes was "als de rerrotte vrugten onder de gaeve", en -dat hij de wereld had verlaten "in eene omstandigheyd die alle eerlyke lieden doen gruwen heeft", terwijl over den predikant Ketelanus was genotuleerd, dat hij om zijn ergerlijk gedrag was weggezonden, bij wion alleen directeur-generaal De Bordes en eene zekere juffrouw Adama aan bet $\mathrm{H}$. Arondmaal kwamen; de andere leden wilden niet communiceeren bij "een ecclesiasticq, die vry wat smetten op zynen mantel had". Voorts had Capitein in dit Kerkeboek gevonden, dat 42 jaar lang, te weten tot op 5 April 1733, het Arondmaal niet was bediend. Van 1683-1736 waren maar vijf huwelijken kerkelijk bevestigd. En dit waren, naar het Capitein roorkwam, nog maar uittreksels uit vorige geschriften, na Ketelanus' ' vertrek gemakkt; de oorspronkelijke waren, zeker om het kwaad dat or in aangeteekend stond, eenvoudigweg verduisterd. Of het opzienersambt dus ook reracht was, behoefde men niet te vragen. In dezen zijnen brief d.d. 1 Juli 1745 tot de Bewindhebberen gericht is Capitein moedeloos; bij wil het werk maar neerleggen en vraagt om ontslag, "want indien onse Kerk- en School-staet altoos soo moet blyren, als by nu nog is, dan suaden sy hun oogmerk bereykt hebben, die hier soo leeven alsof God aen deese plaets niet ware, en die gaern sagen; dat het school 
te niete ging, en dat wel niet, omdat sy daerroor sorg draegen, neen, ganschelijk niet, maer uyt hoope, dat $z \mathrm{y}$ en bunne nakomelingen van alle de minste onkosten souden berreydt worden". Als het bleef zooals het was, dan waren toch eigenlijk al die onkosten aan zijne opleiding besteed vruchteloos geweest; maar wat hemzelf betrof, hij wilde wel alle voordeelen voorbijzien, en tot in het laatste uur zijns levens in het Evangelie werkzaam zijn ${ }^{1}$ ).

Het kan niet ontrend worden, dat de „bediendens" - de ambtenaren in dienst van de Compagnie - hem menigmaal grof behandelden. Hoe zouden ook deze blanke kolonisten respekt bebben voor zulk een Afrikaanschen Moor, al had hij in Europa zijne opleiding genoten! Onder hen was het rooral de fiscaal Huibert van Rijk, die zoowel in het publiek als in tegenwoordigheid van leden van den kerkeraad, op eene verachtelijke wijze over den predikant en den godsdienst sprak en durfde beweren: "dat hy niet anders als uyt nieuwsgierigheid in de kerk kwam". Hij schold de leden van den raad voor schelmen uit en wenschte wel de gebeele wereld te kunnen bedriegen ${ }^{2}$ ). $\mathrm{Op}$ den 18den Maart 1743 gaf directeur-generaal $\mathrm{De} \mathrm{Pe}$. tersen bij gelegenheid van zijnen geboortedag een vroolijke maaltijd aan den raad on "de verdere Heeren en Messieurs, om de vrindschap te cultiveeren". Na afloop bleven sommigen nog wat napraten en onder hen: de fiscaal Huibert $\operatorname{van}$ Rijk en de predikant Capitein. De fiscaal begon te $z$ wetsen, dat hij de kerk alleen uit nieuwsgiorigheid bezocht on „verdere ongerijmde expressien" meer, ja, bij wenschte wel, „dat hy de geheele weereld konde k....n ('t geen in civielder term gezegt is : bedriegen), en dat hy alsdan, zulks ook niet zoude nalaaten". En dat alles werd in tegenwoordigheid van Capitein gezegd ${ }^{3}$ ).

1) Bijlage IX (1 Juli 1745).

2) Missive van dir. gen. De Petersen en vier getuigen aan de Bewindhebberen (10 April 1743) in: Brieven en Papieren van Guinea aan de Kamer van Amsterdam - W.I.C., No. 489, fol. 1:-2.

3) Brieven en Papieren van Guinea uan de Kamer van.Amsterdam W.I. C., No. 489, fol. 3r-4: (19 Manrt 1743). 
Deze Van Rijk, een bon-viveur van de echte soort, had veel van het klimaat te lijden, inzonderheid van het rongesonde saisoen" "an 1745, waarin de langdurige regens en de mist de lucht dermate infecteerden, dat ${ }_{n}$ de natuurlyke en noodige transpiratie van de mensch verhindert (wert)". Herstelden de meeste Europeanen "met quackelende siektens" '), De Rijk's kwaal verergerde zoodanig, dat hï 14 Februari 1747 wegens gezondheidsredenen om ontslag vroeg. Hij werd gekweld - zoo schreef bij met "dolle koortzen en krankheeden", -die $n$ van dat êffect sijn geweest, dat deselve het blootleggende zeenuwengespan bebben doen aangrypen, en na onlydelyke pynen al myne verdere kragten hebben benoomen, met een paar lamne en beroerde armen en handen laate leggen, onmagtig tot iets, dan om nagt en dag te aanschouwen de instrumenten waarmeede ik God, mijn erenmensch en myselven moet verheerlyken, als twee doode klompe vlees voor my te zien leggen, dat nog het chagrinanste van allen is". De chirurgijns badden hem aangeraden van klimaat te veranderen, om "nieuw roedsel en circulatie van sappen te krygen" ${ }^{2}$ ). Door deze ziekte werd zijn humeur nog prikkelbaarder en luchtte hij zijne booze buien op den predikant.

De positie van Capitein werd langzamerhand, als predikant ten minste, onhoudbaar. Ontmoedigd door zooveel tegenwerking, verslapte $h i j$ in zijnen ijver en ging naar winstgevender betrekking uitzien. Hij legde zich op den handel toe, waarin hij zich echter financiëel rolkomen geruïneerd heeft. Het merkwaardigste van alles is echter, dat bij intusschen den Bewindhebberen in zijne breed gestyleerde brieven een rad roor de oogen draaide, en bij hen den schijn trachtte te bewaren, alsof hï nog steeds ijverig in zijn ambt van predikant werkzaam was. $Z i j$

1) Briecen en Papieren van Guinea aan de Kamer van Amsterdam W. I. C., No. 489, fol. 356r-r (22 Sept. 1745).

2) Brieven en Papieren van Guinea aan de Bamer van Amsterdam W. I. C., No. 489, fol. 540r-541r (14 Febr. 1747). 
lieten dan ook niet na hem van tijd tot tijd eenige geschenken ter aanmoediging te sturen. Inzonderheid toen hij dien moedeloozen brief dd. 1 Juli 1745 had geschreven en om ontslag had gevraagd, hadden de Bewindhebberen hem, over die ontslagaanvrage wïselijk zwïgend, eenige versnaperingen toegezonden, waarroor Capitein 23 Mei 1746 in de volgende bewoordingen dank zegde: „By den ontrangst van deesen (sc. brief) sag ik my begivtigt met eene aengenaeme en mildaedige vereering $\operatorname{van}$ verversing, bestaende in welgepakte en welgebleevene hammen, tabak, pypen, roode en witte wynen, en verscheydene liqueren, welke my door syne Edelheyd den heer directeur-generael deeser kuste in haer gebe日l ter hande sijn bestelt geworden. Welke uytwerking nu al dit geschenk ten doorlugtigsten bewyse van U. WE. Gr. A. welmeenend toeleg, om Immanuel Jesus duurgekogte gegemeynte hier ook voort te planten, gehadt hebbe op mijn en myner mede-christenen gemoed, en op dat van ons heydendom, kan is ter uytdrukkinge van myne hartgrondige dankbaerheyd en sonderlinge blïdschap met geene genoegsaeme woorden beschryven" ${ }^{1}$ ).

Niet tegenstaande al dit moois, verzaakte Capitein zijne roeping en stak zich door den handel, diep in de schulden. Wü weten dit uit eenè missive van directeur-generaal De Petersen aan de Bewirdhebberen, kort na Capitein's dood in 1747, geschreven, en ook uit enkele schuldvorderingen op den predikant. De Bewindhebberen badden aan De Petersen 9 Mei 1746 doen weten, dat zij met leedwezen hadden vernomen, hoe er onder de "bediendens van de Compagnie" gevonden werden, die Capitein's arbeid bespotten en trachtten vruchteloos te maken. Zij verzochten den directeur-generaal derhalve de "conduiten van sodanige bediendens" tegen te gaan en te bewerken "dat de predikant niet werde bespot en beschimpt en alsoo moedeloos gemakkt, nee maar effectueeren, dat

1) Bijlage XI (23 Mlei 1746), blz. 273, 
hy in sijn persoon en caracter gemaintineert, en na behoren gerespecteert werde" ${ }^{1}$ ).

Deze onjuiste voorstelling van zaken kon De Petersen niet onder zich laten en daarom schreef hï 1 April 1747, in naam van nog zeven andere ambtenaren ${ }^{2}$ ), aan de Bewindhebberen terug, dat een nauwkeurig ingesteld onderzoek hem had doen zien, dat dit ergerlijke gedrag had bestaan uit "beuselingen, niet weerd om gerepeteerdt to werden", roor welke overtreding zij nog daarenboven gecorrigeerd waren. Maar nu wilde hï eens iets over Capitein mededeelen. Het zou met bewijzen zïn te staven ndat niets anders wylen den predikant sig zelven heeft doen vergeeten, als de ongemeene eer en de groote gunsten, die hem met zän komst alhier, en geduurende zijn verblijf by continuatie vrugteloos zijn beweesen geworden, en dat den zugt roor den coophandel, die wylen zijn Eerwaerde meer als eens ernstig is afgeraaden geworden, zynen fter voor de ordinaire godsdienst zodanig heeft doen verflauwen, dat het ons onder reverentie gezegt, die oog- en oorgetuygen zijn geweest van wylen zijn Eerwaerdes gedrag, belaglijk voorkomt, dat hy in zyne brieven aan $U$ WelEd. Gr. A. heeft durven gewag maaken van zyne pogingen en godrrugtigen arbeydt om het heydendom te bekeeren" 3).

Ook eenige schuldrorderingen op Capitein zijn bekend. Op 13 Mei 1746 gaf hij een obligatio aan Nikolaas Matthias van der Noot de Gietere, groot 2528 gld., 15 stuivers op de Bewindhebberen der West-Indische Compagnie, met verzoek die som uit zijn verdiende gage te betalen. Capitein werd 27 Dec. 1746 tot betaling van dit bedrag

1) Brieven naar Guinea van de Thienen - W. I. C., No. 57, fol. 65r-67r (9 Mei 1746).

2) De namen van hen, die dezen brief onderteekenden, waren behalve De Petersen: Jan van Voorst, Huybert van Rijk, H. Raems, P. B. Verschuuren, B. Coeimans, G. D. Sandra, H. v. Abkoude.

3) Brieven en Papieren van Guinea aan de Pergadering der Thienen - W. I. C., No. 113, fol. 447r-450' (1 April 1747). Lecta in de vergadering der Thienen 1 Oct. 1749. 
gedagvaard. Op dienzelfden dag wordt hij nog eens gedagvaard voor een som van 1815 gld. en tot betaling van een obligatie groot 5225 gld. - waarop reeds 2400 gld. was afgedaan - en waarran de chirurgijn Simon van Burren de houder was. Deze obligatie dagteekende al van 1 October 1741, dus nog van voor zijn vertrek naar Afrika. Capitein verzoekt zïnen schuldeischers nog wat geduld te hebben, waarop Van Buuren antwoordt, niet veel vertrouwen in een predikant te hebben, die telkens zegt: "ik heb het niet; verkoop mijn bed, 't is geen schande. Laat ongerust wezen diegenen, die geld hebben moeten, maar niet diegenen die geld schuldig zijn". Capitein's echtgenoote Antonia Ginderdros stemt met hem in, waarop Van Buuren het bewijs levert, dat Capitein gezegd heeft: „Wat meent Van Buuren wel, dat ik mijn tafel zal verminderen en mijn buik te kort doen om zijnentwil. Neen, dat niet, dat niet!" Eenige dagen later 30 December 1746 - verklaart Capitein bij akte, behalve de som van 8477 gld. 15 stuivers, nog schuldig te zijn aan Alexander Jacob, gew ezen gasthuisvader te D'Elmina, 1200 gld., en aan Hendrik van Keulen, wijnkooper te Amsterdam, 79 gld. Voor het gebeele bedrag geeft hij een obligatie, om "by tijd en wyle" uit zijn te vorderen gagie alles te voldoen ${ }^{1}$ ).

Al deze zorgen zullen zijn einde bespoedigd hebben. Capitein overleed den 1sten Februari 1747 - dertig jaar oud -, nalatende aan de nakomelingschap een niet ongerepten naan, en aan zijne vrouw „een insolventen boedel, die door desselfs weduwe is gerepudieert, ende ten behoeve van de crediteuren geabandonneert geworden" 2).

1) De Navorscher, Jaarg. 27 (1877), blz. 50, 51.

2) Missive van dir.-gen. De Petersen en zeven ambtenaren aan de Bewindhebberen (1 April 1747), in: Brieven en Papieren van Guinea. aan de Vergadering der Thienen - W. I. C., No. 113, fol. 447-450r. Op de "Lijst der Overleedene bediendens op de kust van Guinea in Africa ider voor hun kamer t'zeedert ultimo Dec. 1746 tot ultimo Maart 1747" komt voor: "Primo Febr. 1747, Jacobus Eliza Johannes Capitein". Brieven en Papieren van Guinea aan de Verg. der Thienen - W. L. C., No. 113, blz. 481 r. 
Het leven van dezen eersten, in Europa geordenden negerpredikant, dat zoo goed begon is wel droevig geeindigd. Allerlei factoren werkten hiertoe mede. De kolonisten hadden reeds om zijn huidskleur weinig eerbeid voor dezen $z$ warten prediker; de eigen landgenooten toonden maar geringe belangstelling in zijn werk on belemmerden hem „in (s)ïn voornaemste oogmerk, welk (was) om (s)yne maegschappy naer den vleesche, de Africaensche Mooren, te winnen" ${ }^{1}$ ); door zijn openhartig mededeelen van de fouten en gebreken der kolonisten bijv. in zijn Kerk- en School-staat had hij zich hunne haat op den hals gehaald; zijn ontaktrol optreden in zake bet huwelijk met eene negerin verhoogde zijn aanzien bij kolonist en inboorling geenszins; ten slotte was ook de lust tot handeldrijzen, in plaats van de getrouwe waarneming van zijn ambt, oorzaak van zijn val. Dat hij in de schulden kwam laat zich eenigermate verklaren, als men weet, dat bï nog elk jaar van zijn traktement groot 1200 gld. niet minder dan 300 gld., door bemiddeling van notaris Nesker, "volgens (s)ynen altoos duurenden verschuldigden pligt" aan zïnen weldoener $\nabla$ an Goch moest betalen ${ }^{2}$ ), en als men verder bedenkt, dat de Compagnie hare ambtenaren verplichtte binnen de vier jaar, de opbrengst van twee jaar gagie en emolumenten, onder het beheer der Compagnie te laten, opdat deze "des te geruster mag zijn", dat zị hunne verplichtingen zouden nakomen ${ }^{3}$ ). Zoo had de directeurgeneraal Jacob de Petersen toen hij 31 Maart 1747 met bet schip „Waatervlied" repatriëerde bij de kamer Amsterdam nog een "saldo van gage" van ruim 15157 gld. 4). Geen wonder dat Capitein, die zonder geld wilde handel drïjen, zich in de schulden stak.

1) Bijlage II (15 Febr. 1743), blz. 246.

2) Bijlage V (25 Nov. 1743), blz. 256.

3) Resolutien van de Vergadering der Thienen - W. I. C., No. T, fol. 115r (17 Sept. 1726).

4) Brieven en Papieren van Guinea aan de Vergadering der Thie. nen - W. I. C., No. 113, fol. 483r.

XIII. 
Dat de weinige resultaten, welke hij op z̈jnen arbeid zag, hem moedeloos makkten, kunnen wij begrijpen, als wij in een brief van directeur-generaal De Petersen zelf dd. 1 Juli 1745 lezen: „Hoe langer dat ik hier ben, en hoe meer dat ik de genies van de Naturellen doorgrond, hoe moeielyker on onmogelyker, dat het my toeschïnd, dat, sonder dat er mirakelen geschieden, dezelve tot het Christendom sullen konnen் werden overgebragt, en dat bet eenigste middel omme hierin door de tijd te reusseeren soude weezen de jonge kinderen na een expresse colonie, ofte binnen een bemuurde stad te vervoeren, omme daar door de Christenen in de godsdienst en andere oeffeningen, van jongs aff aan te werden onderweezen, en bequaam gemakkt 1), steunende myne anmerkingen principael op deze sekere gronden, die ik weet dat waaragtigh zijn, en een yder die in deeze gewesten maar de minste observation. heeft genomen ontrent het gedrag der Naturellen sal moeten affirmeren, dat namentlijk de ouders in haare kinderen de hoererye en dievery niet alleen niet en straffen, maar greetige deelgenoten zijn, sonder sig te informeeren waar bet vandaan komt, van hetgeene door hunne kinderen van beyde de sexen gestolen is, en door de vrouwelyke sexe off dogters op een onbetamelyke wyze verdiend" 2 ).

De bewering, welke men wel eens hoort opperen, dat Capitein aan den drank zou zïn geraakt, heb ik nergens bevestigd gevonden ${ }^{3}$ ). Bovendien zouden de Bewindheb.

1) Een dergelijke gedachte koesterde de predikant Jonas Michaēlius in 1628 ten opzichte van de Indianen in Noord-Amerika. Zie mijn : De Hervormde kerk in Noord-Amerika, 's-Grav. 1913, DI. I, blz. 45.

2) Missive van dir. gen. De Petersen aan de Bewoindhebberen (1 Juli 1745), in : Brieven en Papieren van Guinea aan de Vergadering dor Thienen - W.I.C., No. 113, fol. 320i-321r.

3) Van Jan Kompany, den neger, dien Michiel Adriaansz. de Ruiter, in zijn jeugd op het schip tot rriend had, en dien de zeeheld in het jaar 1664 in Afrika, ais onderkoning, terugvond, wordt verhaald, dat hij zijn christen-zijn met eene genegenheid tot den brandewijn zeer wel kon vereenigen. G. Brandt, Het Leven en Bedryf wan den Heere Michiel de Ruiter, A mst. $1691, \mathrm{blz}, 6,312-313,317$. 
beren aan een dronkaard geen wijnen en likeuren hebben gezonden, en diens wijn-rekening zou zeker hooger zïn geweest dan 79 gld. Dat hij door zijne landgenooten vermoord zou zijn is ook onwaar, want dan zou de directeur-generaal De Petersen in den brief waarin hij Capitein's overlïden mededeelt, en zijn doopceel ligt, dit wel niet verzwegen hebben. Maar het is ook eene eenzj̈dige voorstelling der dingen, hare oorzaak hebbende in gebrek aan kennis van de feiten, wanneer men schrijft, dat Capitein in 1747 nna een trouwen arbeid in dienst $\operatorname{van}$ zijn goddelijken zender" is bezweken. 